\title{
The flavonoid profile of pigeonpea, Cajanus cajan: a review
}

\author{
Aaron Nix, Cate A Paull ${ }^{*}$ and Michelle Colgrave
}

\begin{abstract}
Background: Pigeonpea is ranked as the sixth largest grain legume produced by volume and as such is a major global food crop for livestock and human consumption. We show that pigeonpea contains a number of flavonoids and report their distribution and concentration within different parts of the plant.

Findings: There are a total of 27 flavonoids reported in the literature representing seven flavonoid classes. We found no published evidence of flavanols (catechins/flavan-3-ols) or aurones reported from pigeonpea, nor any study of the flavonoids from pigeonpea flowers.

Conclusions: Despite over 40 years of research in to various aspects of pigeonpea we identified research gaps related to the phytochemical properties of pigeonpea. We explain how addressing these gaps could help to realise the full potential of pigeonpea in agricultural production.
\end{abstract}

Keywords: Flavones; Isoflavones; Flavonols; Flavanones; Helicoverpa.spp

\section{Introduction}

Flavonoids are a large group of polyphenolic compounds produced by plants and play important roles within various organs to maintain plant health, development and growth (Falcone Ferreyra et al. 2012). Flavonoids can function as phytoalexins, photoprotectors, and in Leguminosae, nod inducers for nitrogen-fixing bacteria. Flavonoids have been shown to affect the feeding behaviour of invertebrate pest species (Green et al. 2003) and flavonoid profiles have also been used in plant chemotaxonomy to elucidate phylogenetic relationships (Emerenciano et al. 2001). Profiling flavonoids has also enabled the validation of the floral origin of honey (Tomas-Barberan et al. 2001) and the ability to identify varieties of sorghum (Dykes et al. 2009).

Pigeonpea, Cajanus cajan, [(L.) Millspaugh] is a perennial legume (subfamily Papilionoideae) grown in many developing countries in the semi-arid tropics and subtropics ( $\mathrm{Zu}$ et al. 2006). Cajanas cajan is the sole crop from the subtribe Cajaninae (tribe Phaseoleae). The genus Cajanus is comprised of 34 species, of which 17 are from Australia (15 endemic) with most of the remaining species found on the Indian subcontinent (Van der Maesen 1985, 2003). Often cultivated as an annual (Fu et al. 2006), pigeonpea is

\footnotetext{
* Correspondence: Cate.Paull@csiro.au

CSIRO Agriculture Flagship, GPO Box 2583, Brisbane QLD 4001, Australia
}

a major grain legume crop ranked sixth in area and production globally (Fu et al. 2008). It is an important source of protein in human diets used in dhal and as a green vegetable (Saxena 2010; Singh et al. 1984). Dried seeds of pigeonpea are also crushed and used for animal feed (Fu et al. 2008), and more recently transgenic varieties of pigeonpea have enabled the delivery of protective antigens through fodder for livestock (Satyavathi et al. 2003). Pigeonpea is also used as a mandated refuge crop in Australian cotton production to help reduce the likelihood of Helicoverpa species developing resistance to $B t$ cotton (Baker and Tann 2013).

Mounting evidence on the biological activities of flavonoids has increased interest in the possible applications of these compounds in medicine and plant/agricultural sciences. Concurrently, with advances in extraction methods (e.g. microwave-assisted, enzyme-assisted, ultrasonic) and detection using high performance liquid chromatography (HPLC) (Chen et al. 2011), there has been an increase in the ability of researchers to identify flavonoids present in plant material. In this paper we distil all known information on the flavonoid profile of pigeonpea, to facilitate further explorations on the chemical ecology of this species and possible interactions with Helicoverpa armigera. 
Flavonoids of pigeonpea: within-plant distribution and function

Flavonoids are found throughout various plant organs in pigeonpea. The biological activities of the flavonoid classes (Figure 1) and their roles in plant defence may be indicative of their distribution throughout the plant (Falcone Ferreyra et al. 2012). A total of 27 flavonoids have been identified, consisting of six flavones, eight isoflavones, four flavonols, two anthocyanins, three flavanones, three isoflavanones and a single chalcone (Table 1).

\section{Leaves}

Pigeonpea leaves are the richest flavonoid containing organ in the plant and are reported to contain six flavones, two isoflavones, two flavonols, two flavanones, an isoflavanone and the single chalcone.

Leaves are the only part of pigeonpea that are recorded as containing flavones which is likely linked to their role in photoprotection against UV irradiation as has been observed in a number of other plant species (Julkunen-Tiitto et al. 2014). The effects of UV application on post-harvest pigeonpea leaves demonstrated that orientin, luteolin, apigenin and apigenin-6,8-di-C- $\alpha$-l-arabinopyranoside all increased in concentration in response to varying levels of
UV exposure post-harvest compared to the control, i.e. no post-harvest UV exposure (Edwards et al. 2008; Wei et al. 2013b).

Orientin and vitexin are among the most abundant flavonoids in pigeonpea leaves with reported concentrations of $18.82 \mathrm{mg} / \mathrm{g}$ and $21.03 \mathrm{mg} / \mathrm{g}$ respectively (Wu et al. 2009). With the exceptions of the flavanone, pinostrobin and the anthocyanin, chrysanthemin the concentration of other flavonoids from pigeonpea are variable and typically less than $1 \mathrm{mg} / \mathrm{g}$ (Table 2).

Biochanin A and formononetin (also known as biochanin B) are the only isoflavones reported from leaves (Wei et al. 2013a). Isoflavonoids are frequently reported as phytoalexins and are important components in plant defence (Dahiya et al. 1984; Marley and Hillocks 2002; Dahiya 1987). Formononetin has been shown to act as a phytoalexin in the etiolated stems of $C$. cajan, and its primary role may be as a precursor to the primary antifungal compound, the isoflavanone cajanol (Ingham 1976). Pinostrobin chalcone is the sole chalcone described from pigeonpea and its occurrence is only reported from the leaves which were challenged with the necrotic fungus Botrytis cinerea (Cooksey et al. 1982); it is also hypothesized to play a role in photo-protection (Wei et al. 2013b).<smiles>COc1cc2c(=O)cc(-c3ccccc3)oc2c(C)c1O</smiles>

Flavone<smiles>O=c1c(-c2ccccc2)coc2ccccc12</smiles>

Isoflavone<smiles>O=C(/C=C/c1ccccc1)c1ccccc1</smiles>

Chalcone<smiles>O=c1c(O)c(-c2ccccc2)oc2ccccc12</smiles>

Flavonol<smiles>Oc1cc2ccccc2[o+]c1-c1ccccc1</smiles>

Anthocyanidin<smiles>O=C1CC(c2ccccc2)Oc2ccccc21</smiles>

Flavanone

Figure 1 Generalised flavonoid structure with numbering based on flavone skeleton. 


\begin{tabular}{|c|c|c|c|c|}
\hline Flavonoid class & Name & Structure & Organ isolated from & Reference \\
\hline \multirow[t]{6}{*}{ Flavones } & Apigenin & 5,7,4'-trihydroxyflavone & Leaves & Fu et al. (2008); Zu et al. (2006); Wei et al. (2013a); Wei et al. (2013b) \\
\hline & Vitexin & Apigenin 8-C-glucoside & Leaves & Fu et al. (2007); Wu et al. (2009) \\
\hline & Isovitexin & Apigenin 6-C-glucoside & Leaves & Fu et al. (2007) \\
\hline & $\begin{array}{l}\text { Apigenin-6,8-di-C-a--- } \\
\text { arabinopyranoside }\end{array}$ & & Leaves & Wei et al. (2013b) \\
\hline & Luteolin & $5,7,3^{\prime}, 4^{\prime}$-tetrahydroxyflavone & Leaves & Fu et al. (2008); Fu et al. (2006); Wei et al. (2013b); Zu et al. (2006) \\
\hline & Orientin & Luteolin 8-C-glucoside & Leaves & Wei et al. (2013b); Wu et al. (2009) \\
\hline \multirow[t]{8}{*}{ Isoflavones } & Biochanin A & 5,7-Dihydroxy-4'-methoxyisoflavone & Leaves \& roots & Duker-Eshun et al. (2004); Wei et al. (2013a) \\
\hline & Cajanin & 5, 2',4'-Trihydroxy-7-methoxyisoflavone & Seed \& etiolated stems & Dahiya et al. (1984); Ingham (1976) Dahiya (1987) \\
\hline & 4'-O-methylcajanin & 5,2'-dihydroxy-7,4'dimethoxyisoflavone & Etiolated stems & Ingham (1976) \\
\hline & Cajaisoflavone & & Root bark & Bhanumati et al. (1979a) \\
\hline & Formononentin & 7-hydroxy-4'methoxyisoflavone & Etiolated stems \& leaves & Ingham (1976); Wei et al. (2013a) \\
\hline & Genistein & 5,7,4'-trihydroxyisoflavone & Roots/root bark \& etiolated stems & Bhanumati et al. (1979b); Duker-Eshun et al. (2004); Ingham (1976) \\
\hline & $2^{\prime}$-Hydroxygenistein & $5,7,2^{\prime}, 4^{\prime}$-tetrahydroxyisoflavone & Roots, etiolated stems & Duker-Eshun et al. (2004) Ingham (1976) \\
\hline & Isogenistein 7-glucoside & 5,7,2'-trihydroxyisoflavone 7-0- $\beta$-D-glucoside & Root bark & Bhanumati et al. (1979b) \\
\hline \multirow[t]{4}{*}{ Flavonols } & Quercetin & $3,5,7,3^{\prime}, 4^{\prime}$-pentahydroxyflavone & Leaves \& pod surface & Green et al. (2003); Zu et al. (2006) \\
\hline & Isoquercitrin & Quercetin 3- $\beta$-D-glucoside & Pod surface & Green et al. (2003) \\
\hline & 3-O-Methylquercetin & $5,7,3^{\prime}, 4^{\prime}$-Tetrahydroxy-3-methoxyflavone & Pod surface & Green et al. (2003) \\
\hline & Isorhamnetin & 3'-Methoxyquercetin & Leaves & Zu et al. (2006) \\
\hline \multirow[t]{2}{*}{ Anthocyanidins } & Chrysanthemin & Cyanidin 3-glucoside & Location not reported & Lai et al. (2012) \\
\hline & Peonidin 3-glucoside & & Location not reported & Lai et al. (2012) \\
\hline \multirow[t]{3}{*}{ Flavanones } & Cajaflavanone & & Root \& root bark & Dahiya (1991); Bhanumati et al. (1978) \\
\hline & Naringenin & $5,7,4^{\prime}$-trihydroxyflavanone & Leaves & Wei et al. (2013b) \\
\hline & Pinostrobin & 5-hydroxy-7-methoxyflavanone & Leaves & $\begin{array}{l}\text { Wei et al. (2013a); Wei et al. (2013b); Wu et al. (2009); Ashidi et al. } \\
\text { (2010); Duker-Eshun et al. (2004); Kong et al. (2010); Nicholson et al. (2010) }\end{array}$ \\
\hline \multirow[t]{3}{*}{ Isoflavanone } & Cajanol & 5,4'-dihydroxy-7,2'-dimethoxyisoflavanone & $\begin{array}{l}\text { Roots, stem/etiolated stems, } \\
\text { leaves \& seed }\end{array}$ & $\begin{array}{l}\text { Wei et al. (2013a); Liu et al. (2011); Luo et al. (2010); Dahiya et al. (1984); } \\
\text { Duker-Eshun et al. (2004); Marley and Hillocks (2002); Ingham }(1979,1976) \\
\text { Dahiya (1987) }\end{array}$ \\
\hline & Cajanone & & Roots & Dahiya (1991); Preston (1977) \\
\hline & 2'-O-Methylcajanone & & Root bark & Bhanumanti et al. (1979) \\
\hline Chalcone & Pinostrobin chalcone & 2',6'-Dihydroxy-4'-methoxychalcone & Leaves & Cooksey et al. (1982); Wei et al. (2013b) \\
\hline
\end{tabular}


Table 2 Concentrations ( $\mathrm{mg} / \mathrm{g}$ of plant material) of flavonoids reported from Cajanus cajan

\begin{tabular}{|c|c|c|c|}
\hline Flavonoid & $\begin{array}{l}\text { Plant } \\
\text { organ }\end{array}$ & $\begin{array}{l}\text { Concentrations } \\
(\mathrm{mg} / \mathrm{g})\end{array}$ & Reference \\
\hline 2'-Hydroxygenistein & Stem & $0.037^{\mathrm{a}}$ & Ingham (1976) \\
\hline 4'-0-methylcajanin & Stem & $0.022^{\mathrm{a}}$ & Ingham (1976) \\
\hline \multirow[t]{3}{*}{ Apigenin } & Leaves & $0.130^{b}$ & Zu et al. (2006) \\
\hline & & $0.132^{\mathrm{a}}$ & Fu et al. (2008) \\
\hline & & $0.159^{b}$ & Wei et al. (2013a) \\
\hline Biochanin A & Leaves & $0.405^{b}$ & Wei et al. (2013a) \\
\hline Cajanin & Stem & $0.074^{a}$ & Ingham (1976) \\
\hline \multirow[t]{2}{*}{ Cajanol } & Stem & $0.370^{a}$ & Ingham (1976) \\
\hline & Leaves & $0.369^{b}$ & Wei et al. (2013a) \\
\hline Chrysanthemin & & $2.250^{b}$ & Lai et al. (2012) \\
\hline Formonentin & Leaves & $0.318^{b}$ & Wei et al. (2013a) \\
\hline Genistein & Stem & $0.105^{a}$ & Ingham (1976) \\
\hline Isorhamnetin & Leaves & $0.091^{b}$ & Zu et al. (2006) \\
\hline \multirow[t]{2}{*}{ Luteolin } & Leaves & $0.263^{b}$ & Zu et al. (2006) \\
\hline & & $0.268^{\mathrm{a}}$ & Fu et al. (2008) \\
\hline Orientin & Leaves & $18.82^{b}$ & Wu et al. (2009) \\
\hline Peonidin 3-glucoside & & $0.540^{b}$ & Lai et al. (2012) \\
\hline \multirow[t]{3}{*}{ Pinostrobin } & Leaves & $3.500^{b}$ & Kong et al. (2010) \\
\hline & & $5.548^{\mathrm{b}}$ & Wei et al. (2013a) \\
\hline & & $30.29^{b}$ & Wu et al. (2009) \\
\hline Quercetin & Leaves & $0.082^{b}$ & Zu et al. (2006) \\
\hline Vitexin & Leaves & $21.03^{b}$ & Wu et al. (2009) \\
\hline
\end{tabular}

NB. The highest mean yield (extraction concentration, $\mathrm{mg} / \mathrm{g}$ ) is reported here ${ }^{a}$ concentration reported from fresh material, ${ }^{b}$ concentration reported from dried material.

\section{Roots, seedling stems and seed}

The roots, stem and seed of pigeonpea almost exclusively contain isoflavonoids. The exception is the flavanone, cajaflavanone which has been reported from the roots (Bhanumati et al. 1978; Dahiya 1991). The isoflavones formononentin, genistein, 2'-hydroxygenistein and cajanin, and the isoflavanone cajanol were isolated from etiolated stems of pigeonpea inoculated with the fungus $H$. carbonum while being restricted to trace levels in uninfected plants (Ingham 1976). Cajanol was found to be the primary antifungal compound produced by pigeonpea when tested against different fungal pathogens (Ingham 1976; Marley and Hillocks 2002). The isoflavanone cajanone was also shown to inhibit the growth of the pigeonpea wilt pathogen Fusarium oxysporum (Preston 1977).

Investigating the accumulation of phytoalexins showed the presence of cajanol, cajanin, isoprenylated genistein and an unidentified isoflavonoid phytoalexin in pigeon pea after seedlings had been stressed with silver nitrate solution and subjecting them to dark conditions. No phytoalexins were present in stressed seedlings exposed to light (Dahiya 1987).

The isoflavanone cajanone and the flavanone, cajaflavanone have been isolated from root exudates and shown to be responsible for nitrogen nodulation (Dahiya 1991).

Pigeonpea seeds have received little attention. However, seeds that had been soaked, then sliced and incubated under non-sterile conditions accumulated the phytoalexins cajanol, cajanin and two unidentified isoprenylated flavones (Dahiya et al. 1984).

Compounds identified from the surface of pods included three flavonoids, the flavonols quercetin, isoquercitrin (quercetin-3-glucoside) and quercetin 3-methyl ether, and the stilbene, cajaninstilbene acid (CSA). Behavioural studies of larvae of the agricultural pest, Helicoverpa armigera demonstrated quercetin 3-methyl ether increased their feeding behaviour while CSA was found to be a feeding deterrent. Pod-boring-resistant cultivars were found to have a higher ratio of CSA to quercetin 3-methyl ether, along with an increase in isoquercitrin and an absence of quercetin on the pod surface, when compared to the commonly cultivated susceptible varieties (Green et al. 2003).

Flavonoid glycosides have received significant attention in health research due to their antioxidant and anticancer properties (March et al. 2006). Pigeonpea contains vitexin and isovitexin, two flavone $\mathrm{C}$-glucosides known to possess antimicrobial effects (Agnese et al. 2001). Orientin, another flavone $\mathrm{C}$-glucoside from pigeonpea, has been shown to possess higher antioxidant activities and more efficient free radical scavenging abilities than vitexin (Wu et al. 2009). Luteolin is a flavone found in high concentration in pigeonpea leaves (Fu et al. 2006) and exhibits a number of pharmacological properties (Lee et al. 2002; Kimata et al. 2000; Perez-Garcia et al. 2000).

There have not been any reports of flavonoid compounds from pigeonpea flowers to date.

\section{Conclusions}

The literature about pigeonpea flavonoids spans almost 40 years. However, there are relatively few published studies and from these we presented a total of 27 flavonoids across seven classes. Despite the importance of pigeonpea as an economic crop for both human and animal nutrition, we show here that the knowledge of flavonoids from pigeonpea and their potential application is largely undeveloped. In particular, there is limited understanding of how the flavonoid profile of pigeonpea affects interactions with insect pest species. For example, cultivated varieties of pigeonpea are susceptible to pod-boring insects, such as Helicoverpa armigera, a major agricultural pest, which feed on all plant parts including the seed (Jadhav et al. 2012). However, despite flavonoids being found in the seeds of most plants and coloured flowers, we could only find one published study of flavonoids in pigeonpea seed and none 
reporting flavonoids from flowers. Based on evidence that suggests specific flavonoids on the surface of the pods affect feeding behaviour (Green et al. 2003) we suggest extending research to include analysis, detection and measurement of the levels of these compounds in all plant parts (particularly flowers). This could be useful to develop varieties of pigeonpea that have increased resistance to pests such as Helicoverpa thereby maximising yields.

We suggest that further work exploiting the advances in technology used to isolate, characterise and quantify flavonoids could be applied to enhance plant breeding and allow the agricultural production potential of pigeonpea to be realised.

\section{Competing interests}

The authors declare that they have no competing interests.

\section{Authors' contributions}

AN is the main author, who reviewed previous literature and wrote the manuscript. CP proposed the topic and together with MC supervised the work, provided ideas and contributed with writing and reviewing the manuscript. All authors read and approved the final manuscript.

\section{Acknowledgements}

The authors thank the two anonymous referees for their helpful suggestions and comments about the manuscript. We would also like to thank CSIRO Agriculture Flagship for funding this research.

Received: 30 December 2014 Accepted: 25 February 2015 Published online: 13 March 2015

\section{References}

Agnese AM, Perez C, Cabrera JL (2001) Adesmia aegiceras: antimicrobial activity and chemical study. Phytomedicine 8(5):389-394, doi:10.1078/0944-7113-00059

Ashidi JS, Houghton PJ, Hylands PJ, Efferth T (2010) Ethnobotanical survey and cytotoxicity testing of plants of South-western Nigeria used to treat cancer, with isolation of cytotoxic constituents from Cajanus cajan Millsp leaves. J Ethnopharmacol 128(2):501-512, doi:10.1016/j.jep.2010.01.009

Baker GH, Tann CR (2013) Mating of Helicoverpa armigera (Lepidoptera: Noctuidae) moths and their host plant origins as larvae within Australian cotton farming systems. Bull Entomol Res 103(2):171-181, doi:10.1017/s0007485312000508

Bhanumanti S, Chhabra SC, Gupta SR, Krishnamoorthy V (1979) 2'-O-methylcajanone: a new isoflavanone from Cajanus cajan. Phytochemistry 18(4):693, http://dx.doi.org/10.1016/S0031-9422(00)84304-6

Bhanumati S, Chhabra SC, Gupta SR, Krishnamoorthy V (1978) Cajaflavanone: a new flavanone from Cajanus cajan. Phytochemistry 17(11):2045-2045, doi:10.1016/s0031-9422(00)88770-1

Bhanumati S, Chhabra SC, Gupta SR (1979a) Cajaisoflavone, a new prenylated isoflavone from Cajanus cajan. Phytochemistry 18(7):1254-1254

Bhanumati S, Chhabra SC, Gupta SR, Krishnamoorthy V (1979b) New isoflavone glucoside from Cajanus cajan. Phytochemistry 18(2):365-366, doi:10.1016/0031-9422(79)80111-9

Chen ML, Hu W, Zhang C, Fang Y (2011) High performance liquid chromatography for the determination of flavonoids. J Chin Pharmaceut Sci 20(4):313-324

Cooksey CJ, Dahiya JS, Garratt PJ, Strange RN (1982) Two novel stilbene-2-carboxylic acid phytoalexins from Cajanus cajan. Phytochemistry 21(12):2935-2938

Dahiya JS (1987) Reversed-phase high-performance liquid chromatography of Cajanus cajan phytoalexins. J Chromatogr A 409(C):355-359

Dahiya JS (1991) Cajaflavanone and cajanone released from Cajanus cajan (L. Millsp.) roots induce nod genes of Bradyrhizobium sp. Plant Soil 134(2):297-304, doi:10.1007/bf00012049

Dahiya JS, Strange RN, Bilyard KG, Cooksey CJ, Garratt PJ (1984) 2 isoprenylated isoflavone phytoalexins from Cajanus cajan. Phytochemistry 23(4):871-873, doi:10.1016/s0031-9422(00)85046-3
Duker-Eshun G, Jaroszewski JW, Asomaning WA, Oppong-Boachie F, Christensen SB (2004) Antiplasmodial constituents of Cajanus cajan. Phytother Res 18(2):128-130

Dykes L, Seitz LM, Rooney WL, Rooney LW (2009) Flavonoid composition of red sorghum genotypes. Food Chem 116(1):313-317, doi:10.1016/j. foodchem.2009.02.052

Edwards WR, Hall JA, Rowlan AR, Schneider-Barfield T, Sun TJ, Patil MA, Pierce ML, Fulcher RG, Bell AA, Essenberg M (2008) Light filtering by epidermal flavonoids during the resistant response of cotton to Xanthomonas protects leaf tissue from light-dependent phytoalexin toxicity. Phytochemistry 69(12):2320-2328, doi:10.1016/.jphytochem.2008.05.021

Emerenciano VP, Militao J, Campos CC, Romoff P, Kaplan MAC, Zambon M, Brant AJC (2001) Flavonoids as chemotaxonomic markers for Asteraceae. Biochem Syst Ecol 29(9):947-957, doi:10.1016/s0305-1978(01)00033-3

Falcone Ferreyra ML, Rius SP, Casati P (2012) Flavonoids: biosynthesis, biological functions, and biotechnological applications. Front Plant Sci 3:222, doi:10.3389/fpls.2012.00222

Fu YJ, Zu YG, Liu W, Efferth T, Zhang NJ, Liu XN, Kong Y (2006) Optimization of luteolin separation from pigeonpea Cajanus cajan (L.) Millsp. leaves by macroporous resins. J Chromatogr A 1137(2):145-152, doi:10.1016/j. chroma.2006.08.067

Fu YJ, Zu YG, Liu W, Hou CL, Chen LY, Li SM, Shi XG, Tong MH (2007) Preparative separation of vitexin and isovitexin from pigeonpea extracts with macroporous resins. J Chromatogr A 1139(2):206-213, doi:10.1016/j.chroma.2006.11.015

Fu YJ, Liu W, Zu YG, Tong MH, Li SM, Yan MM, Efferth T, Luo H (2008) Enzyme assisted extraction of luteolin and apigenin from pigeonpea Cajanus cajan (L.) Millsp. leaves. Food Chem 111 (2):508-512, doi:10.1016/j.foodchem.2008.04.003

Green PWC, Stevenson PC, Simmonds MSJ, Sharma HC (2003) Phenolic compounds on the pod-surface of pigeonpea, Cajanus cajan, mediate feeding behavior of Helicoverpa armigera larvae. J Chem Ecol 29(4):811-821, doi:10.1023/A:1022971430463

Ingham JL (1976) Induced isoflavonoids from fungus-infected stems of pigeon pea (Cajanus cajan). ZNaturforsch(C) 31(9-10):504-508

Ingham JL (1979) A revised structure for the phytoalexin cajanol. ZNaturforsch(C) 34(1-2):159-161

Jadhav DR, Nalini M, Abhishek R, Dilip P (2012) Effect of some flavonoids on survival and development of Helicoverpa armigera (Hubner) and Spodoptera litura (Fab) (Lepidoptera: Noctuidae). Asian J Agr Sci 4(4):298-307

Julkunen-Tiitto R, Nenadis N, Neugart S, Robson M, Agati G, Vepsäläinen J, Zipoli G, Nybakken L, Winkler B, Jansen MAK (2014) Assessing the response of plant flavonoids to UV radiation: an overview of appropriate techniques. Phytochem Rev. doi:10.1007/s11101-014-9362-4

Kimata M, Inagaki N, Nagai H (2000) Effects of luteolin and other flavonoids on lgEmediated allergic reactions. Planta Med 66(1):25-29, doi:10.1055/s-2000-11107

Kong Y, Zu YG, Fu YJ, Liu W, Chang FR, Li J, Chen YH, Zhang S, Gu CB (2010) Optimization of microwave-assisted extraction of cajaninstilbene acid and pinostrobin from pigeonpea leaves followed by RP-HPLC-DAD determination. J Food Compos Anal 23(4):382-388, doi:10.1016/j.jfca.2009.12.009

Lai YS, Hsu WH, Huang JJ, Wu SC (2012) Antioxidant and anti-inflammatory effects of pigeon pea (Cajanus cajan L.) extracts on hydrogen peroxide- and lipopolysaccharide-treated RAW264.7 macrophages. Food Funct 3(12):1294-1301, doi:10.1039/c2fo30120b

Lee LT, Huang YT, Hwang JJ, Lee PPH, Ke FC, Nair MP, Kanadaswami C, Lee MT (2002) Blockade of the epidermal growth factor receptor tyrosine kinase activity by quercetin and luteolin leads to growth inhibition and apoptosis of pancreatic tumor cells. Anticancer Res 22(3):1615-1627

Liu XL, Zhang XJ, Fu YJ, Zu YG, Wu N, Liang L, Efferth T (2011) Cajanol inhibits the growth of Escherichia coli and Staphylococcus aureus by acting on membrane and DNA damage. Planta Med 77(2):158-163, do::10.1055/s-0030-1250146

Luo M, Liu X, Zu YG, Fu YJ, Zhang S, Yao LP, Efferth T (2010) Cajanol, a novel anticancer agent from Pigeonpea Cajanus cajan (L.) Millsp. roots, induces apoptosis in human breast cancer cells through a ROS-mediated mitochondrial pathway. Chem-Biol Interact 188(1):151-160, doi:10.1016/j.cbi.2010.07.009

March RE, Lewars EG, Stadey CJ, Miao X-S, Zhao X, Metcalfe CD (2006) A comparison of flavonoid glycosides by electrospray tandem mass spectrometry. Int I Mass Spectrom 248(1-2):61-85, http://dx.doi.org/10.1016/j.jims.2005.09.011

Marley PS, Hillocks RJ (2002) Induction of phytoalexins in pigeonpea (Cajanus cajan) in response to inoculation with Fusarium udum and other treatments. Pest Manag Sci 58(10):1068-1072, doi:10.1002/ps.586

Nicholson RA, David LS, Le Pan R, Liu XM (2010) Pinostrobin from Cajanus cajan (L.) Millsp inhibits sodium channel-activated depolarization of mouse brain synaptoneurosomes. Fitoterapia 81(7):826-829, doi:10.1016/j.fitote.2010.05.005 
Perez-Garcia F, Adzet T, Canigueral S (2000) Activity of artichoke leaf extract on reactive oxygen species in human leukocytes. Free Radic Res 33(5):661-665, doi:10.1080/10715760000301171

Preston NW (1977) Cajanone: an antifungal isoflavanone from Cajanus cajan. Phytochemistry 16(1):143-144, doi:10.1016/0031-9422(77)83040-9

Satyavathi W, Prasad V, Khandelwal A, Shaila MS, Sita GL (2003) Expression of hemagglutinin protein of Rinderpest virus in transgenic pigeon pea Cajanus cajan (L.) Millsp. plants. Plant Cell Rep 21(7):651-658, doi:10.1007/s00299-002-0540-2

Saxena KB (2010) Quality nutrition through pigeonpea-a review. Health 02(11):1335-1344, doi:10.4236/health.2010.211199

Singh U, Jain KC, Jambunathan R, Faris DG (1984) Nutritional quality of vegetable pigeon peas Cajanus cajan (L.) Millsp: mineral and trace elements. J Food Sci 49(2):645-646, doi:10.1111/j.1365-2621.1984.tb12489.x

Tomas-Barberan FA, Martos I, Ferreres F, Radovic BS, Anklam E (2001) HPLC flavonoid profiles as markers for the botanical origin of European unifloral honeys. J Sci Food Agr 81(5):485-496, doi:10.1002/jsfa.836

Van der Maesen LG (1985) Cajanus DC. and Atylosia W. \& A. (Leguminosae): A Revision of all Taxa Closely Related to the Pigeon Pea, With Notes on Other Related Genera within the Subtribe Cajaninae, vol 85, Wageningen Agricultural University Papers, vol 4. Agricultural University Wageningen, Wageningen, Netherlands

Van der Maesen LG (2003) Cajaninae of Australia (Leguminosae: Papilionoideae). Aust Syst Bot 16(2):219-227, http://dx.doi.org/10.1071/SB01047

Wei Z, Zu Y, Fu Y, Wang W, Luo M, Zhao C, Pan Y (2013a) lonic liquids-based microwave-assisted extraction of active components from pigeon pea leaves for quantitative analysis. Sep Purif Technol 102:75-81, doi:10.1016/j. seppur.2012.09.031

Wei ZF, Luo M, Zhao CJ, Li CY, Gu CB, Wang W, Zu YG, Efferth T, Fu YJ (2013b) UV-induced changes of active components and antioxidant activity in postharvest pigeon pea [Cajanus cajan (L.) Millsp.] leaves. J Agric Food Chem 61(6):1165-1171

Wu N, Fu K, Fu YJ, Zu YG, Chang FR, Chen YH, Liu XL, Kong Y, Liu W, Gu CB (2009) Antioxidant activities of extracts and main components of Pigeonpea [Cajanus cajan (L.) Millsp.] leaves. Molecules 14(3):1032-1043, doi:10.3390/ molecules14031032

Zu YG, Fu YJ, Liu W, Hou CL, Kong Y (2006) Simultaneous determination of four flavonoids in pigeonpea Cajanus cajan (L.) Millsp. leaves using RP-LC-DAD. Chromatographia 63(9-10):499-505, doi:10.1365/s10337-006-0784-z

\section{Submit your manuscript to a SpringerOpen ${ }^{\circ}$ journal and benefit from:}

- Convenient online submission

- Rigorous peer review

- Immediate publication on acceptance

- Open access: articles freely available online

- High visibility within the field

- Retaining the copyright to your article

Submit your next manuscript at $>$ springeropen.com 